\title{
PENERAPAN PENDEKATAN SCIENCE, TECHNOLOGY, ENGINEERING, AND MATHEMATICS (STEM) DALAM PEMBELAJARAN MATEMATIKA DI SMK PADA JURUSAN BISNIS KONSTRUKSI DAN PROPERTI
}

\author{
Lihitta Dwita
}

Pendidikan Matematika, FMIPA, Universitas Negeri Surabaya, $e$-mail: lihittadwita16030174076@mhs.unesa.ac.id

\section{Susanah}

Pendidikan Matematika, FMIPA, Universitas Negeri Surabaya, $e$-mail: $\underline{\text { susanah@unesa.ac.id }}$

\begin{abstract}
Abstrak
Pelaksanaan proses pembelajaran pada kurikulum 2013 menuntut peserta didik untuk terlibat aktif dalam setiap kegiatan pembelajaran. Untuk menciptakan hal tersebut perlu diterapkannya suatu inovasi yang baru dalam kegiatan pembelajaran. STEM merupakan singkatan dari Science, Technology, Engineering, dan Mathematics. Keempat aspek STEM tersebut dapat menciptakan peserta didik memiliki keterampilan abad 21 di antaranya komunikasi, kolaborasi, berpikir kritis, dan kreativitas yang berguna bagi peserta didik untuk bersaing pada abad 21. Tujuan dari penelitian ini adalah untuk mendeskripsikan kemampuan guru dalam mengelola pembelajaran, aktivitas peserta didik, hasil belajar peserta didik, dan respons peserta didik terhadap pembelajaran matematika dengan menerapkan pendekatan STEM. Data dikumpulkan menggunakan lembar pengamatan kemampuan guru mengelola pembelajaran, lembar pengamatan aktivitas peserta didik, tes hasil belajar, dan angket respons. Jenis penelitian ini adalah deskriptif dengan pendekatan kualitatif. Hasil penelitian ini menunjukkan bahwa: (1) kemampuan guru dalam mengelola pembelajaran dengan menerapkan pendekatan STEM termasuk dalam kategori sangat baik dengan perolehan skor ratarata sebesar 3,53; (2) aktivitas peserta didik selama mengikuti pembelajaran dengan menerapkan pendekatan STEM terdapat 5 aktivitas yang sesuai dan 5 aktivitas yang tidak sesuai dengan rentang waktu ideal yang disusun berdasarkan RPP; (3) hasil belajar peserta didik di lihat dari nilai tes hasil belajar yang menyatakan sebanyak 23 dari 25 peserta didik telah tuntas dalam jarak antara dua titik dan jarak titik terhadap garis pada ruang dimensi tiga dengan memperoleh persentase ketuntasan belajar klasikal sebesar 92\%; dan (4) respons peserta didik secara keseluruhan mempunyai respons positif dengan rata-rata persentase respons $82,4 \%$.
\end{abstract}

Kata Kunci: Pembelajaran Matematika, Pendekatan STEM, STEM.

\section{Abstract}

The implementation of the learning process in the curriculum 2013, requires students to be actively involved in every learning activity. To create this, it is necessary to apply a new innovation in learning activities. STEM is an abbreviation of Science, Technology, Engineering, and Mathematics. These four aspects of STEM can help students have 21st century skills in communication, collaboration, critical thinking, and creativity that are useful for students to compete in the 21 st century. This research aims to describe teacher's proficiency manages teaching process, student's activity, learning output, and students' response towards learning mathematics by applying the STEM approach. The method of this research is descriptive with qualitative and quantitative approach. The data are gathered by using observation, test, and questionnaire methods. The result of this research showed that: 1) teacher's proficiency in managing the learning process using STEM approach was categorized as very good with average score of 3,53; (2) the activities of students during the learning process by applying the STEM approach there are 5 appropriate activities and 5 inappropriate activities with the ideal timeframe which arranged by RPP; (3) the learning output based on recapitulation of final test showed that 23 of 25 students had already passed the material of the distance between two points and the distance between a point and a line in dimension three with earned the percentage of completeness success classically $92 \%$; and (4) the student's responses overall has a positive response with an average percentage of responses $82,4 \%$.

Keywords: Mathematics Learning, STEM approach, STEM. 


\section{PENDAHULUAN}

Dalam merencanakan dan melaksanakan kegiatan pembelajaran pada kurikulum 2013, seorang pendidik diharuskan untuk menciptakan kegiatan pembelajaran yang menunjang keaktifan partisipasi dari peserta didik saat kegiatan pembelajaran. Untuk menciptakan kegiatan pembelajaran tersebut, seorang pendidik perlu merancang suatu perangkat pembelajaran yang berkualitas dan bermutu agar tercapainya tujuan pembelajaran.

Permendikbud Nomor 103 Tahun 2014 mengemukakan bahwa, pendekatan pembelajaran merupakan cara pandang pendidik yang digunakan untuk menciptakan lingkungan pembelajaran yang memungkinkan terjadinya proses pembelajaran dan tercapainya kompetensi yang ditentukan.

Pendekatan pembelajaran dalam kurikulum 2013 ialah pendekatan pembelajaran yang mendorong peserta didik untuk terlibat aktif dalam setiap kegiatan belajar mengajar sehingga peserta didik dapat mencapai keterampilan penguasaan iptek yang menjadi kunci penting dalam tuntutan abad ke 21 (Saleha, 2019).

Upaya yang dilakukan Indonesia dalam mengoptimalkan sumber daya manusia dan memaksimalkan penguasaan iptek melalui pendidikan ialah dengan menyiapkan jalur pendidikan kejuruan atau yang dikenal dengan sekolah menengah kejuruan atau SMK. Lulusan SMK dirancang oleh pemerintah dengan tujuan agar peserta didik siap memasuki dunia kerja dengan mengandalkan keterampilan-keterampilan khusus sesuai dengan bidang kejuruan yang telah dipelajarinya.

Dalam mencapai kualitas lulusan sekolah menengah kejuruan tersebut perlu didasari dengan adanya kurikulum, pendekatan pembelajaran serta model pembelajaran yang dirancang dan dikembangkan dengan prinsip kesesuaian kebutuhan peserta didik SMK. Rancangan kegiatan pembelajaran yang berlangsung diterapkan di sekolah menengah kejuruan biasanya berkaitan dengan pembelajaran untuk memecahkan berbagai masalah dalam kehidupan nyata.

STEM merupakan suatu pendekatan dalam pembelajaran. STEM singkatan dari sains (Science), teknologi (Technology), enjiniring (Engineering), dan matematika (Mathematics). Keempat aspek dalam STEM merupakan aspek-aspek dalam pembelajaran di mana keempat aspek tersebut berkaitan erat dengan permasalahan dalam kehidupan sehari-hari dan dunia pekerjaan (Torlakson, 2014).

Devi, P.K., dkk. (2018) menjelaskan bahwa, STEM (science, technology, engineering, dan mathematics) adalah sebuah pendekatan dalam pembelajaran yang memadukan keempat disiplin ilmu yang berguna untuk menyelesaikan permasalahan dalam kehidupan nyata serta dapat mengembangkan daya cipta peserta didik agar memiliki keterampilan-keterampilan abad ke 21.

Pengertian pendekatan STEM pada penelitian ini adalah suatu pendekatan pembelajaran yang mengintegrasikan keempat aspek STEM (science, technology, engineering, dan mathematics) untuk menyelesaikan permasalahan dalam kehidupan nyata yang melibatkan proses berpikir kreatif, kritis, dan kolaborasi sehingga menciptakan peserta didik berketerampilan abad 21.

Tujuan STEM dapat menuntut peserta didik bagaimana memecahkan suatu masalah, berpikir kreatif dalam memecahkan masalah, berpikir kritis untuk memecahkan masalah, serta mampu menciptakan sebuah hasil pemecahan masalah yang dapat dimanfaatkan untuk menghadapi tantangan abad ke-21 (Saleha, 2019). Berkaitan dengan hal tersebut tujuan pendekatan STEM menurut Devi, dkk. (2018) yaitu meningkatkan literasi STEM pada peserta didik, mengembangkan kompetensi abad 21, serta menciptakan peserta didik berkemampuan STEM. Terdapat empat aspek teori STEM dalam penelitian ini yaitu sebagai berikut.

1. Sains (Science)

Sains merupakan proses mencari tahu tentang sesuatu yang melibatkan pengamatan terkait fenomena alam untuk menjelaskan secara objektif dari gejala-gejala yang terjadi di alam. Ciri-ciri aspek sains pada pendekatan STEM di antaranya: (1) mengamati suatu permasalahan terkait dengan fenomena alam, (2) mengajukan pertanyaan, (3) mengumpulkan informasi, (4) menalar, dan (5) menyampaikan atau mengomunikasikan hasil pengamatan.

2. Teknologi (Technology)

Teknologi merupakan suatu perangkat atau alat yang digunakan oleh manusia untuk mempermudah menyelesaikan permasalahan dalam kehidupan sehari-hari. Ciri-ciri aspek teknologi pada pendekatan STEM di antaranya: (1) menggunakan teknologi seperti internet, geogebra, aplikasi autocad, dsb dalam pembelajaran. Teknologi tersebut dapat digunakan oleh guru maupun peserta didik, (2) mempermudah dan membantu peserta didik dalam menyelesaikan masalah. Sebagai contoh, peserta didik dapat menggunakan aplikasi geogebra untuk memvisualisasikan bentuk-bentuk bangun geometri dengan cepat dan teliti dibandingkan dengan menggunakan peralatan seperti jangka, busur, pensil, dan penggaris.

3. Enjiniring (Engineering)

Enjiniring merupakan pengetahuan untuk mendesain sebuah prosedur untuk menyelesaikan sebuah permasalahan. Ciri-ciri aspek enjiniring pada 
pendekatan STEM di antaranya: (1) melibatkan peserta didik dalam merancang/mendesain sebuah prosedur. Kegiatan tersebut dapat mengembangkan ide dan mengasah keterampilan peserta didik dalam membuat suatu konsep desain yang sesuai dengan permasalahan, (2) enjiniring menggunakan konsep sains, matematika, dan alat-alat teknologi dalam merancang/mendesain sebuah prosedur.

4. Matematika (Mathematics)

Matematika merupakan ilmu yang mempelajari tentang pola dan hubungan yang digunakan sebagai bahasa bagi pengetahuan, teknologi, dan enjiniring dalam menyelesaikan masalah. Ciri-ciri aspek matematika pada pendekatan STEM di antaranya: (1) matematika digunakan sebagai bahasa bagi pengetahuan, teknologi, dan teknik/enjiniring. Dalam hal tersebut matematika digunakan sebagai perhitungan dan mengelola data-data terkait dengan penyelesaian masalah, (2) mengaplikasikan topik/subtopik matematika tertentu untuk menyelesaikan masalah. Kegiatan tersebut dapat melatih peserta didik dalam menganalisis dan menentukan topik/subtopik matematika yang mana yang berkaitan dengan permasalahan.

Di samping itu, terdapat pola-pola integrasi dalam pembelajaran dengan pendekatan STEM. Pola-pola tersebut memiliki perbedaan pada konten STEM yang diterapkan. Menurut Robert dan Cantu (2012) terdapat tiga pola integrasi dalam pembelajaran dengan pendekatan STEM yaitu pola pendekatan terpisah/silo, pola pendekatan embedded/tertanam, dan pola pendekatan terintegrasi.

1. Pola pendekatan terpisah/silo

Dalam penelitian ini pola pendekatan terpisah yaitu pendekatan di mana peserta didik akan belajar satu materi atau satu aspek dari pendekatan STEM (science, technology, engineering, dan mathematics). Keadaan tersebut lebih tepat digambarkan dengan S-TE-M daripada STEM. Karena mata pelajaran atau aspek-aspek dalam STEM diajarkan saling terpisah satu sama lain dan tidak terintegrasi.

2. Pola pendekatan embeddedtertanam

Dalam penelitian ini pola pendekatan tertanam yaitu pendekatan di mana peserta didik akan belajar dengan satu disiplin STEM sebagai materi utama dan tiga disiplin STEM yang lain sebagai materi pendukung yang menjadi penguat dan pelengkap konsep.

3. Pola pendekatan terintegrasi

Dalam penelitian ini pola pendekatan terintegrasi yaitu pendekatan di mana peserta didik akan belajar keempat disiplin STEM secara utuh sebagai materi yang terintegrasi.
Penerapan pembelajaran dengan pendekatan STEM dalam penelitian ini menggunakan pola pendekatan tertanam dengan aspek matematika sebagai materi utama. Aspek sains, teknologi, dan enjiniring menjadi materi pendukung yang tidak dinilai dan tidak dievaluasi.

Di samping hal tersebut terdapat dua penekanan pengertian pendekatan, khususnya dalam pembelajaran matematika yaitu (Susanah dkk., 2014): (1) pendekatan materi (material approach) yaitu pembelajaran suatu topik/subtopik matematika tertentu menggunakan materi matematika lain, dan (2) pendekatan pembelajaran (instructional approach) yaitu pembelajaran materi matematika tertentu dengan cara atau metode atau teknik tertentu agar peserta didik mudah memahaminya. Kedua pendekatan tersebut dimaksudkan untuk mempermudah peserta didik dalam memahami pelajaran, tetapi berbeda penekanan.

Berkaitan dengan aspek matematika yang menjadi materi utama dan penekanan pendekatan di atas, maka pendekatan STEM dalam pembelajaran matematika merupakan pendekatan materi. Dengan pendekatan tersebut pelaksanaan pembelajaran yang dilakukan oleh peserta didik tidak hanya belajar satu materi matematika saja, tetapi peserta didik dapat menggunakan materi matematika yang lain yang mungkin berkaitan dengan tiga aspek STEM yang lain.

Penerapan pendekatan STEM dalam pembelajaran matematika merupakan salah satu solusi dalam pembelajaran dengan keterampilan abad 21 (Saleha, 2019). Keterampilan abad 21 menjadi bahan pembicaraan beberapa waktu terakhir yang banyak dibahas di Indonesia. Sebab Indonesia memiliki minim tenaga kerja atau lulusan dengan keterampilan abad 21. Zubaidah (2016) menjelaskan bahwa, Indonesia memiliki tenaga kerja dan lulusan dengan keahlian rendah dan kurang terlatih dibandingkan dengan tenaga kerja dan lulusan dari Filipina.

Keterampilan abad 21 melatih setiap individu untuk memiliki keterampilan-keterampilan khusus yang dikenal dengan 21 st Century Skills atau dikenal dengan "The $4 C s$ communication, collaboration, critical thinking, and creativity" (P21, 2008). Yang artinya komunikasi, kolaborasi, berpikir kritis, dan kreativitas. Menurut Winaryati (2018), empat jenis keterampilan tersebut merupakan keterampilan-keterampilan yang harus dimiliki oleh seseorang saat terjun dalam dunia pekerjaan pada zaman sekarang. Hal tersebut berkaitan erat dengan SMK yang diprogram oleh pemerintah untuk mencetak lulusan sekolah menengah yang memiliki keterampilanketerampilan khusus agar siap bekerja dan terampil dalam bidang keahliannya.

Jurusan bisnis konstruksi dan properti (BKP) merupakan salah satu jurusan yang ada di sekolah 
menengah kejuruan (SMK). Jurusan ini mempelajari ilmu konstruksi bangunan, pengukuran tanah, rancangan anggaran biaya (RAB), konstruksi bangunan, dll. Jurusan tersebut merupakan awal atau dasar bagi peserta didik sebelum menjadi seorang arsitek, kontraktor, konsultan bangunan, ataupun semacamnya.

Dalam pembelajarannya peserta didik jurusan BKP akan diajarkan mengenai dasar-dasar ilmu konstruksi bangunan dan teknik menggambar yang meliputi menggambar sebuah garis, menggambar bentuk-bentuk bidang dua dan tiga dimensi, menggambar proyeksi benda hingga menggambar dengan menggunakan perangkat seperti (Suparno, 2008). Pada teknik-teknik menggambar tersebut peserta didik akan dikaitkan dengan matematika di mana peserta didik akan dihadapkan dengan bagianbagian dari geometri yang meliputi titik, garis, dan bidang.

Pembelajaran matematika sangat perlu diterapkan dalam bidang-bidang keahliannya sekolah menengah kejuruan. Dengan mempelajari matematika peserta didik dapat mengetahui manfaat dan hubungan antar materi matematika dengan materi program keahliannya. Bidang keahlian merupakan kumpulan dari beberapa program keahlian yang ditawarkan oleh setiap sekolah menengah kejuruan. Misalnya teknologi dan rekayasa, teknologi informasi dan komunikasi, dsb. Sehingga pembelajaran matematika sangat berhubungan dengan konteks dari bidang keahlian tersebut. Matematika berfungsi sebagai pembentuk pola pikir bagi peserta didik dalam membuat suatu keputusan, bernalar hingga memecahkan masalah. Sehingga melalui fungsi tersebut belajar matematika dapat meningkatkan kompetensi pemahaman, pemecahan masalah, berpikir kritis, komunikasi, dan koneksi yang ada di dalam diri peserta didik.

Berkaitan dengan uraian-uraian di atas peneliti tertarik untuk melakukan penelitian yang berjudul "Penerapan Pendekatan Science, Technology, Engineering, and Mathematics (STEM) dalam Pembelajaran Matematika di SMK pada Jurusan Bisnis Konstruksi dan Properti”.

Tujuan dari penelitian ini yaitu untuk mendeskripsikan bagaimana kemampuan guru dalam mengelola pembelajaran, aktivitas peserta didik, hasil belajar peserta didik, dan respons peserta didik terhadap pembelajaran dengan menerapkan pendekatan Science, Technology, Engineering, and Mathematics (STEM) dalam pembelajaran matematika di SMK pada jurusan bisnis konstruksi dan properti.

Kemampuan guru dalam mengelola pembelajaran pada penelitian ini adalah kecakapan seorang guru yang ditunjukkan untuk menciptakan proses pembelajaran yang optimal dalam melaksanakan setiap tahap pembelajaran yang runtut sesuai dengan rancangan pelaksanaan pembelajaran (RPP). RPP yang disusun dalam penelitian ini menggunakan pendekatan STEM dan Problem Based Learning sebagai model pembelajaran.

Aktivitas peserta didik dalam penelitian ini adalah suatu kegiatan dan tingkah laku yang dilakukan oleh peserta didik selama mengikuti proses pembelajaran di kelas. Menurut Nurdyansyah (2016) dan Khairiyah (2019) maka aktivitas peserta didik yang dimaksud dalam penelitian ini adalah sebagai berikut.

1. Memperhatikan guru dan teman saat menjelaskan materi atau memberikan sebuah pertanyaan.

2. Merespons guru atau teman saat menyampaikan penjelasan, mengajukan pertanyaan, memberi saran atau tanggapan.

3. Bekerja sama dan saling berdiskusi dengan teman satu kelompok terkait dengan materi pembelajaran yang sedang dipelajari.

4. Mengerjakan Lembar Kerja Peserta didik.

5. Melakukan aktivitas sains seperti mengamati, menanya, mengumpulkan informasi, menalar, hingga mengomunikasikan permasalahan terkait dengan fenomena yang terjadi di alam.

6. Menggunakan teknologi berupa suatu perangkat atau alat untuk mempermudah menyelesaikan permasalahan.

7. Melakukan aktivitas enjiniring/teknik dengan cara mengembangkan ide melalui mendesain sebuah prosedur yang melibatkan permasalahan.

8. Melakukan aktivitas matematika seperti melakukan perhitungan, mengelola data-data, hingga mengaplikasikan topik/subtopik matematika tertentu untuk menyelesaikan masalah.

9. Mempresentasikan hasil Lembar Kerja Peserta didik.

10. Melakukan kegiatan relevan dengan pembelajaran, misalnya memperhatikan teman saat melakukan presentasi, menyimpulkan hingga merangkum materi yang telah diajarkan oleh guru.

Hasil belajar peserta didik yang dimaksud dalam penelitian ini adalah skor atau nilai yang didapat oleh peserta didik setelah mengerjakan soal (THB) tes hasil belajar terkait dengan pembelajaran menerapkan pendekatan STEM.

Respons peserta didik adalah jawaban dari pernyataan yang tersedia pada lembar angket yang telah diberikan kepada peserta didik untuk mengetahui respons peserta didik setelah diterapkannya pembelajaran dengan pendekatan STEM.

Perlu diketahui bahwa penerapan pembelajaran dengan pendekatan STEM dalam proses pembelajaran harus disesuaikan dengan karakteristik materi ajar. Hal ini dilakukan mengingat tidak semua materi dapat dibelajarkan dengan pendekatan STEM. Dalam memilih materi pembelajaran yang sesuai dengan pendekatan STEM perlu dilakukan penganalisisan terlebih dahulu 
(Saleha, 2019). Berikut merupakan langkah-langkah dalam menganalisis materi pembelajaran yang sesuai dengan pendekatan STEM:

1. Melakukan analisis terhadap kompetensi dasar mata pelajaran yaitu kompetensi dasar pengetahuan (KD 3) dan keterampilan (KD 4). Analisis kompetensi dasar ini meliputi analisis sains, teknologi, enjiniring, dan matematika.

2. Menentukan topik pembelajaran dan indikator pencapaian kompetensi.

Dalam kurikulum 2013 terdapat beberapa model pembelajaran yang harus diterapkan guru dalam melaksanakan suatu kegiatan pembelajaran di kelas. Implementasi model pembelajaran yang menjadi karakteristik Kurikulum 2013 pada jenjang sekolah menengah adalah penerapan model pembelajaran saintifik, discovery, model pembelajaran berbasis proyek (PjBL) dan model pembelajaran berbasis masalah (PBL). Dengan menerapkan model-model pembelajaran inovatif tersebut diharapkan nantinya masing-masing sekolah dapat mencetak lulusan yang memiliki kompetensi utuh baik aspek pengetahuan, psikomotor, maupun sikap (Sofyan, 2015).

Dalam menerapkan pendekatan STEM dapat didukung dengan berbagai model pembelajaran (Khairiyah, 2019). Perhatikan gambar di bawah ini.

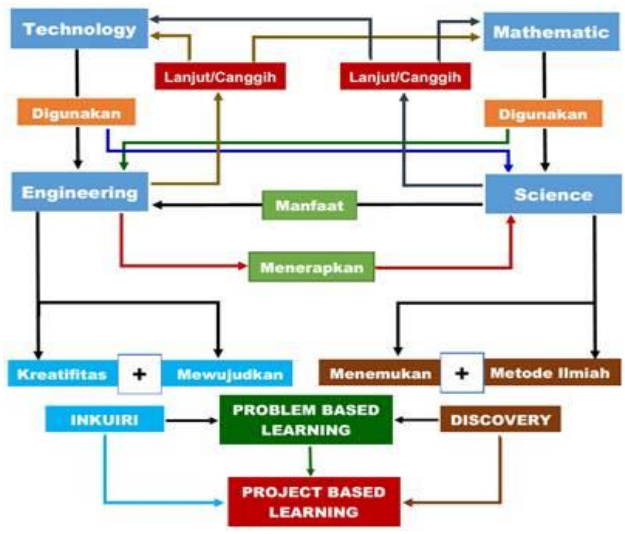

Gambar 1. Keterkaitan Keempat Aspek STEM

Pada gambar di atas keempat aspek STEM berkaitan satu dengan yang lainnya. Seperti matematika yang digunakan untuk sains dan teknologi. Teknologi juga digunakan untuk enjiniring. Kemudian enjiniring menerapkan sains serta sains memanfaatkan enjiniring. Sehingga STEM yang bersifat integratif memungkinkan penerapannya dalam model Problem Based Learning atau model Project Based Learning.

Pada penelitian ini menerapkan pendekatan STEM dengan model pembelajaran berbasis masalah (PBL). Model pembelajaran berbasis masalah merupakan model pembelajaran yang menjadi karakteristik dari Kurikulum 2013 yang disarankan penerapannya dalam pembelajaran di SMK. Penerapan model PBL dapat mengembangkan keterampilan berpikir peserta didik di antaranya penalaran, komunikasi, dan koneksi dalam memecahkan masalah (Trianto, 2007).

Materi yang diajarkan pada penelitian ini adalah materi jarak pada ruang dimensi tiga dengan sub materi jarak antara dua titik dan jarak titik terhadap garis dengan menggunakan Kompetensi Inti (KI) dan Kompetensi Dasar (KD) Kurikulum 2013 Revisi (Peraturan Dirjen Pendidikan Dasar dan Menengah Kemendikbud No.464/D.D5/KR/2018) yang dirancang khusus untuk Sekolah Menengah Kejuruan. Materi tersebut merupakan bagian dari materi dimensi ruang yang dapat menghasilkan bentuk karya arsitektur yang bebas. Sehingga akan sangat bermakna apabila di ajarkan kepada peserta didik SMK jurusan bisnis konstruksi dan properti karena berkaitan erat dengan bidang keahliannya.

\section{METODE}

Jenis penelitian ini adalah penelitian deskriptif dengan menggunakan pendekatan kualitatif. Penelitian deskriptif digunakan untuk mendeskripsikan bagaimana kemampuan guru dalam mengelola pembelajaran, aktivitas peserta didik selama mengikuti pembelajaran, hasil belajar peserta didik, dan respons peserta didik terhadap pembelajaran terkait dengan penerapan pendekatan STEM dalam pembelajaran. Penelitian ini menggunakan rancangan One Shot Case Study, karena dalam penelitian ini hanya satu kelas saja yang dikenakan perlakuan tertentu tanpa adanya kelas kontrol dan tes awal.

Pengambilan data dalam penelitian ini dilaksanakan pada semester genap tahun ajaran 2019/2020 di SMKN 3 Surabaya secara daring dan tidak. Pengambilan data tes hasil belajar (THB) dan pengisian angket respons setelah mengikuti pembelajaran dengan menerapkan pendekatan STEM dilakukan secara daring dengan membuat kelas online via google classroom. Sedangkan pengambilan data kemampuan guru dalam mengelola pembelajaran dan aktivitas peserta didik selama mengikuti pembelajaran dilaksanakan secara langsung di kelas selama dua pertemuan.

Subjek dalam penelitian ini adalah guru matematika dan satu kelas XI peserta didik jurusan BKP SMKN 3 Surabaya. Teknik pengumpulan data dalam penelitian ini yaitu observasi, tes, dan angket.

Data yang diperoleh dalam penelitian ini merupakan hasil pengamatan yang dilakukan oleh seorang mengamat meliputi data kemampuan guru dalam mengelola pembelajaran, data aktivitas peserta didik saat pembelajaran berlangsung selama dua pertemuan, data tes hasil belajar peserta didik setelah menerima materi jarak antara dua titik dan jarak titik terhadap garis, dan data hasil pengisian angket respons peserta didik tentang pembelajaran dengan menerapkan pendekatan STEM pada 
materi jarak antara dua titik dan jarak titik terhadap garis yang telah dilakukan oleh guru.

Perangkat pembelajaran yang digunakan dalam penelitian ini antara lain Rencana Pelaksanaan Pembelajaran (RPP) selama dua pertemuan dan Lembar Kerja Peserta Didik (LKPD) yang terdiri dari LKPD1 dan LKPD2. Sedangkan instrumen dalam penelitian ini berupa lembar pengamatan guru dalam mengelola pembelajaran, lembar pengamatan aktivitas peserta didik, lembar tes hasil belajar, dan lembar angket respons peserta didik. Perangkat pembelajaran dan instrumen penelitian dalam penelitian ini, nantinya akan di validasi oleh dua orang validator. Validasi tersebut bertujuan untuk mengukur kelayakan perangkat pembelajaran dan instrumen penelitian yang akan dipergunakan.

Data yang diperoleh akan dianalisis secara deskriptif dengan penjelasan analisis data sebagai berikut.

1. Analisis Data Kemampuan Guru dalam Mengelola Pembelajaran

Analisis data kemampuan guru dalam mengelola pembelajaran diperoleh berdasarkan data hasil pengamatan yang dilakukan oleh seorang pengamat. Data tersebut akan dihitung rata-rata keseluruhan pada setiap pertemuan dengan memperhatikan tiap-tiap aspek pengelolaan guru yang telah diberi tanda cek $(\sqrt{ })$. Setelah menghitung rata-rata keseluruhan tiap pertemuan langkah selanjutnya yaitu menentukan nilai rata-rata kemampuan guru dalam mengelola pembelajaran secara keseluruhan dari dua kali pertemuan. Berdasarkan perolehan rata-rata pada kedua pertemuan tersebut, peneliti dapat diinterpretasikan nilai rata-rata kemampuan guru dalam mengelola pembelajaran dengan menggunakan kategori sebagai berikut.

Tabel 1. Kategori Kemampuan Guru dalam Mengelola Pembelajaran

\begin{tabular}{|c|c|}
\hline Skor Rata-rata Total & Keterangan \\
\hline $1,00 \leq$ Skor $<1,50$ & Tidak Baik \\
\hline $1,50 \leq$ Skor $<2,50$ & Kurang Baik \\
\hline $2,50 \leq$ Skor $<3,50$ & Baik \\
\hline $3,50 \leq$ Skor $\leq 4,00$ & Sangat Baik \\
\hline
\end{tabular}

2. Analisis Data Aktivitas Peserta Didik

(Masriyah, 2006)

Analisis data aktivitas peserta didik diperoleh berdasarkan data hasil pengamatan yang dilakukan oleh peneliti. Setiap aktivitas yang muncul akan diamati dengan rentang waktu selama 5 menit dan dicatat pada lembar pengamatan yang telah disusun. Data aktivitas peserta didik akan dihitung dengan memperhatikan frekuensi aktivitas yang muncul dan menghitung jumlah aktivitas secara keseluruhan pada setiap pertemuan. Kemudian langkah selanjutnya mencari persentase aktivitas peserta didik pada setiap kategori aktivitas peserta didik menggunakan rumus sebagai berikut (Masriyah, 2006).

$$
=\frac{\begin{array}{c}
\% \text { aktivitas } \\
\sum \text { aspek aktivitas yang } \text { muncul }
\end{array}}{\sum \text { aktivitas secara keseluruhan }} \times 100 \%
$$

Lalu menghitung rata-rata setiap kategori aktivitas peserta didik yang diamati dalam semua pertemuan. Selanjutnya menentukan kesesuaian persentase aktivitas peserta didik terhadap rentang waktu ideal. Dengan kriteria waktu ideal aktivitas peserta didik berpedoman pada penyusunan Rencana Pelaksanaan Pembelajaran (RPP) dengan menerapkan pendekatan STEM.

Langkah terakhir yaitu menjelaskan ada berapa buah aktivitas yang sesuai dan aktivitas yang tidak sesuai dengan rentang waktu ideal yang telah disusun berdasarkan alokasi Rencana Pelaksanaan Pembelajaran (RPP) selama dua pertemuan.

3. Analisis Data Hasil Belajar Peserta didik

Analisis data hasil belajar peserta didik diperoleh berdasarkan skor atau nilai yang didapat peserta didik setelah menerima materi jarak antara dua titik dan jarak titik terhadap garis. Data tes tersebut selanjutnya akan dihitung berapa orang dari 25 peserta didik yang nilainya di atas dan di bawah KKM. Kemudian langkah selanjutnya ialah menentukan persentase keberhasilan pembelajaran klasikal dengan memperhatikan berapa banyak peserta didik yang nilainya di atas KKM. Pembelajaran dengan menerapkan pendekatan STEM dikatakan tuntas apabila banyaknya peserta didik yang tuntas secara individu lebih dari atau sama dengan $75 \%$ dari keseluruhan peserta didik yang ada dalam kelas pembelajaran.

4. Analisis Data Angket Respons Peserta didik

Analisis data angket respons peserta didik diperoleh berdasarkan data hasil respons peserta didik setelah mengisi angket respons yang berisikan lima pernyataan favorable dan lima pernyataan unfavorable terkait pembelajaran dengan pendekatan STEM. Pernyataan favorable dan unfavorable memiliki skor yang berbeda pada tiap kategori jawaban. Data respons dari peserta didik selanjutnya akan dikalikan sesuai dengan ketentuan kategori jawaban peserta didik. Kemudian menjumlahkan semua total nilai respons pada setiap item pertanyaan. Lalu menghitung persentase nilai respons peserta didik pada setiap item pernyataan. Dari persentase tersebut akan dicocokkan kategori dengan persentase respons peserta didik yang disajikan pada tabel di bawah ini (Khabibah, 2006). 
Tabel 3. Kategori Respons Peserta Didik

\begin{tabular}{|c|c|c|}
\hline No. & $\% \boldsymbol{N R S}$ & Kriteria \\
\hline 1. & $0 \% \leq N R S<50 \%$ & $\begin{array}{c}\text { Tidak } \\
\text { Positif }\end{array}$ \\
\hline 2. & $50 \% \leq \% N R S<70 \%$ & $\begin{array}{c}\text { Kurang } \\
\text { Positif }\end{array}$ \\
\hline 3. & $70 \% \leq \% N R S<85 \%$ & Positif \\
\hline 4. & $85 \% \leq \% N R S \leq 100 \%$ & $\begin{array}{c}\text { Sangat } \\
\text { Positif }\end{array}$ \\
\hline
\end{tabular}

Berdasarkan hasil persentase respons peserta didik, respons peserta didik dikatakan positif apabila secara keseluruhan mendapatkan persentase lebih dari $70 \%$.

\section{HASIL DAN PEMBAHASAN}

Berdasarkan hasil pengamatan kemampuan guru dalam mengelola pembelajaran pada pertemuan pertama dan pertemuan kedua dapat disajikan pada diagram di bawah ini.

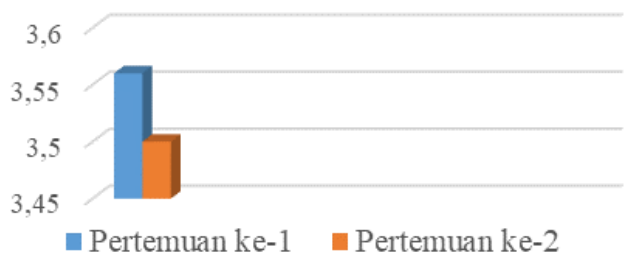

Diagram 1. Perbandingan Skor Rata-Rata Kemampuan Guru dalam Mengelola Pembelajaran

Berdasarkan diagram di atas terjadi penurunan skor rata-rata kemampuan guru dalam mengelola pembelajaran antara pertemuan pertama dengan pertemuan kedua sebanyak 0,06. Hal tersebut terjadi dikarenakan pada pertemuan kedua aspek guru memotivasi peserta didik agar terlibat dalam pemecahan masalah, guru membimbing peserta didik merangkum materi yang telah dipelajari menggunakan geogebra atau powerpoint, guru memimpin jalannya presentasi kelompok dan memberi penekanan pada materi, dan guru melakukan refleksi terkait kegiatan pembelajaran yang telah dilakukan mendapat penurunan skor menjadi 3,00.

Dalam memotivasi peserta didik agar terlibat dalam pemecahan masalah, guru kurang maksimal dalam melakukannya terlihat dari beberapa peserta didik yang tidak ikut serta berdiskusi dengan kelompoknya. Selain itu, pada akhir pembelajaran guru hanya membimbing peserta didik merangkum materi yang telah dipelajari secara lisan tanpa memanfaatkan teknologi yang ada seperti geogebra dan powerpoint. Hal tersebut membuat peserta didik merasa kesulitan saat memvisualisasikan jarak pada bentuk tiga dimensi pada bangun ruang. Kegiatan tersebut kurang sesuai dengan pendapat Firman (2015) bahwa teknologi dapat dimanfaatkan oleh guru dalam pembelajaran dengan pendekatan STEM, karena teknologi merupakan inovasi berupa perangkat atau alat yang diciptakan oleh manusia untuk mempermudah kegiatan manusia dalam menyelesaikan permasalahan dalam kehidupan sehari-hari.

Pada kegiatan inti pembelajaran, guru telah melakukan setiap tahapan pembelajaran sesuai dengan
RPP yang disusun menggunakan pendekatan STEM dengan baik. Guru tidak selalu mendominasi pada saat kegiatan pembelajaran tetapi guru bertindak memfasilitasi dan mengarahkan peserta didik untuk memecahkan permasalahan yang disajikan pada LKPD. Hal tersebut sesuai dengan tujuan pendekatan STEM yang menuntut peserta didik bagaimana menjadi pemecah suatu masalah, berpikir kreatif dan kritis untuk memecahkan masalah, serta mampu menciptakan sebuah hasil pemecahan masalah yang dapat dimanfaatkan dalam kehidupan (Saleha, 2019).

Dalam pelaksanaan pembelajaran ini, guru dituntut untuk menggunakan aspek-aspek dalam pendekatan STEM pada saat kegiatan pembelajaran. Aspek pendekatan STEM yang digunakan oleh guru pada pertemuan pertama hingga pertemuan kedua mengalami peningkatan dari skor 3,00 menjadi skor 4,00 yaitu pada aspek guru meminta peserta didik merancang/mendesain sebuah prosedur enjiniring yang sesuai dengan permasalahan dan guru menggunakan alat-alat teknologi saat kegiatan pembelajaran. Sedangkan pada aspek guru menyajikan permasalahan yang berkaitan dengan sains dan bermakna bagi peserta didik jurusan bisnis konstruksi dan properti dan aspek guru mengaitkan suatu topik/subtopik materi matematika tertentu untuk mempermudah peserta didik dalam menyelesaikan permasalahan mendapatkan skor 4,00 pada kedua pertemuan. Keempat aspek STEM yang telah digunakan oleh guru sesuai dengan prinsip pengertian pendekatan STEM yaitu sebuah pendekatan dalam pembelajaran yang memadukan aspek science, technology, engineering dan mathematics untuk memecahkan masalah dalam kehidupan sehari-hari (Devi dkk, 2018).

Berdasarkan hasil rata-rata kemampuan guru dalam mengelola pembelajaran dengan menerapkan pendekatan STEM secara keseluruhan selama dua kali pertemuan sebesar 3,53. Sehingga kemampuan guru dalam mengelola pembelajaran dengan menerapkan pendekatan STEM berkategori sangat baik.

Berdasarkan pengamatan aktivitas peserta didik yang dilakukan dengan menerapkan pendekatan STEM pada pembelajaran dengan materi jarak antara dua titik dan jarak titik terhadap garis di SMKN 3 Surabaya kelas XI jurusan BKP selama dua pertemuan, dapat dilihat diagram perbandingannya aktivitas-aktivitas peserta didik sebagai berikut.

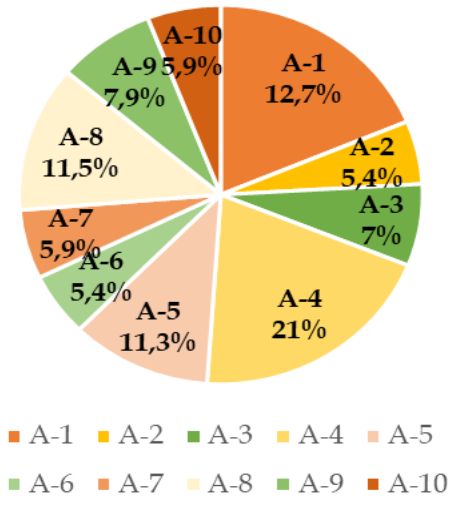

Diagram 2. Persentase Aktivitas Peserta Didik 
Dalam penelitian ini terdapat sepuluh aktivitas yang harus diamati oleh seorang pengamat. Pada diagram lingkaran di atas aktivitas nomor 5, 6, 7, dan 8 merupakan aktivitas peserta didik pada saat melakukan aktivitas aspek dalam pendekatan STEM yaitu sains, technology, engineering, dan mathematics. Sedangkan aktivitas selain nomor tersebut merupakan aktivitas peserta didik berdasarkan langkah-langkah model pembelajaran berbasis masalah (PBL).

Aktivitas yang mengikuti langkah-langkah model pembelajaran berbasis masalah (PBL) yang paling banyak dilakukan adalah aktivitas keempat yaitu mengerjakan lembar kerja peserta didik memperoleh skor rata-rata sebesar $21 \%$ dan sesuai dengan rentang waktu ideal. Hal tersebut dapat terjadi karena LKPD yang dibagikan oleh guru berisikan permasalahan yang akan didiskusikan secara berkelompok oleh peserta didik.

Aktivitas mengerjakan LKPD menjadi aktivitas yang sering muncul pada saat kegiatan pembelajaran, karena peserta didik memerlukan banyak waktu untuk berdiskusi dan mengerjakan LKPD. Hal tersebut sesuai dengan pendapat Nurdyansyah dan Fahyuni (2016) yaitu pada saat peserta didik mengerjakan lembar kerja yang dibagikan oleh guru, peserta didik diminta untuk mengumpulkan data dan melaksanakan eksperimen hingga peserta didik benar-benar memahami dimensi permasalahan yang ada pada lembar kerja tersebut.

Aktivitas STEM merupakan aktivitas inti dalam penelitian ini. Keempat aktivitas aspek dalam pendekatan STEM juga muncul pada saat peserta didik mengerjakan LKPD. Hal tersebut berkaitan dengan pendapat Khairiyah (2019) bahwa lembar kerja peserta didik membantu peserta didik dalam belajar dengan menggunakan pendekatan STEM. Aktivitas STEM yang mendapatkan persentase terbesar adalah aktivitas kedelapan yaitu melakukan aktivitas matematika (mathematics) seperti melakukan perhitungan, mengelola data-data, hingga mengaplikasikan topik/subtopik matematika tertentu untuk menyelesaikan masalah sebesar $11,5 \%$ dan sesuai dengan rentang waktu ideal. Hal tersebut terjadi karena LKPD yang dibagikan oleh guru berisi tentang bahan diskusi peserta didik dengan anggota kelompoknya terkait materi jarak antara dua titik dan jarak titik terhadap garis. Sehingga hal tersebut menyebabkan peserta didik lebih sering melakukan aktivitas matematika seperti melakukan perhitungan, menghubungkan materi matematika yang dipelajari dengan materi matematika yang lain seperti teorema pythagoras, bangun ruang, dsb.

Aktivitas STEM yang sering dilakukan kedua adalah aktivitas kelima yaitu melakukan aktivitas sains (science) seperti mengamati, menanya, mengumpulkan informasi, menalar, hingga mengomunikasikan permasalahan terkait dengan fenomena yang terjadi di alam sebesar 11,30\% dan sesuai dengan rentang waktu ideal. Hal tersebut dapat terjadi karena LKPD disajikan berupa sebuah permasalahan yang melibatkan fenomena yang terjadi di alam. Sehingga sebelum menyelesaikan permasalahan tersebut peserta didik dituntut terlebih dahulu untuk mengamati, menanya, dan mengumpulkan informasi.

Aktivitas STEM yang sering dilakukan ketiga adalah aktivitas ketujuh yaitu melakukan aktivitas enjiniring (engineering) dengan cara mengembangkan ide melalui mendesain sebuah prosedur yang melibatkan permasalahan sebesar $5,85 \%$ dan tidak sesuai dengan rentang waktu ideal. Sebab aktivitas enjiniring ini terjadi secara singkat karena berkaitan dengan bidang keahlian peserta didik jurusan BKP yaitu dalam mensketsa denah sebuah rumah dan mengonstruksi kuda-kuda atap rumah, dimana peserta didik sudah menguasai hal tersebut. Dan aktivitas STEM yang mendapatkan persentase terkecil adalah aktivitas keenam yaitu aktivitas aspek teknologi (technology) sebesar 5,37\% dan tidak sesuai dengan rentang waktu ideal. Sebab teknologi yang digunakan oleh peserta didik yaitu menggunakan internet sebagai sumber untuk mencari/mengumpulkan informasi dan menggunakan kalkulator untuk mempermudah melakukan perhitungan, sehingga aktivitas ini berjalan secara singkat.

Aktivitas yang sering dilakukan selanjutnya adalah aktivitas pertama memperhatikan penjelasan materi yang disampaikan oleh guru dan teman dengan perolehan skor rata-rata $12,7 \%$ dan tidak sesuai dengan rentang waktu ideal. Dari hasil pengamatan dapat diketahui bahwa peserta didik cenderung sering memperhatikan guru dan teman dalam memberi penjelasan. Sehingga hal tersebut kurang sesuai dengan teori Nurdyansyah dan Fahyuni (2016) bahwa pembelajaran PBL berpusat pada masalah autentik yang menuntun peserta didik untuk mengajukan pertanyaan atau masalah.

Selanjutnya aktivitas yang sering dilakukan adalah aktivitas kesembilan yaitu mempresentasikan hasil lembar kerja peserta didik dengan perolehan skor rata-rata sebesar 7,9\% dan kesesuaian terhadap rentang waktu ideal yaitu tidak sesuai. Sebab pada saat mempresentasikan hasil lembar diskusi atau LKPD, peserta didik cenderung tidak memberikan kesempatan kepada kelompok lain untuk berpartisipasi dan juga guru kurang tegas dalam memimpin jalannya presentasi/diskusi.

Aktivitas yang selanjutnya atau aktivitas ketiga yaitu bekerja sama dan saling berdiskusi dengan teman satu kelompok terkait dengan materi pembelajaran yang sedang dipelajari memperoleh skor rata-rata sebesar 7\% dengan kesesuaian terhadap rentang waktu ideal yaitu kurang sesuai. Hal tersebut tidak sesuai dengan pendapat Nurdyansyah dan Fahyuni (2016) bahwa pembelajaran PBL mengorganisasikan peserta didik untuk belajar dengan membentuk kelompok belajar yang bertujuan agar peserta didik saling berdiskusi dengan saling bertukar pendapat.

Aktivitas yang dilakukan selanjutnya adalah aktivitas kesepuluh yaitu melakukan kegiatan relevan dengan pembelajaran, misalnya memperhatikan teman saat presentasi, menyimpulkan atau merangkum materi yang telah dipelajari memperoleh skor rata-rata sebesar 5,9\% dengan kesesuaian rentang waktu ideal yaitu sesuai. Dari data tersebut dapat diketahui bahwa peserta didik cukup terlibat dalam kegiatan menyimpulkan atau merangkum materi.

Aktivitas peserta didik yang paling sedikit dilakukan adalah aktivitas kedua yaitu merespons guru atau teman saat menyampaikan penjelasan, mengajukan pertanyaan, memberi saran atau tanggapan memperoleh skor rata-rata 
sebesar 5,4\% dengan kesesuaian rentang waktu ideal yaitu sesuai. Dari data tersebut dapat diketahui bahwa peserta didik cukup dalam menanggapi pertanyaan atau tanggapan yang disampaikan oleh temannya, sehingga membuat interaksi antar peserta didik baik.

Dengan demikian dapat disimpulkan bahwa aktivitas peserta didik selama mengikuti pembelajaran dengan menerapkan pendekatan STEM selama dua pertemuan terdapat 5 aktivitas yang sesuai dengan rentang waktu ideal dan terdapat 5 aktivitas yang tidak sesuai dengan rentang waktu ideal yang disusun berdasarkan alokasi Rencana Pelaksaan Pembelajaran (RPP).

Berdasarkan data hasil tes belajar peserta didik setelah diterapkan pembelajaran dengan pendekatan STEM, dapat ditarik kesimpulan bahwa nilai rata-rata hasil belajar kelas XI jurusan BKP SMKN 3 Surabaya pada materi jarak antara dua titik dan jarak titik terhadap garis sebesar 82,32. Pelaksanaan tes hasil belajar tersebut dilakukan secara online via google classroom, dengan waktu pengerjaan tes selama 1 jam.

Standar KKM pada mata pelajaran matematika yang telah ditetapkan di SMKN 3 Surabaya yaitu peserta didik dianggap tuntas apabila skor peserta didik dapat melebihi 75 dari atau sama dengan 75. Nilai ketuntasan belajar klasikal peserta didik diambil dari skor tes hasil belajar (THB) selama dua pertemuan setelah peserta didik menerima semua materi yang diajarkan oleh guru. Sehingga berdasarkan data yang telah diperoleh terdapat dua peserta didik yang tidak tuntas dalam mengerjakan tes hasil belajar tersebut.

Skor tes hasil belajar yang tinggi atau di atas KKM menunjukkan bahwa peserta didik memahami materi jarak antara dua titik dan jarak titik terhadap garis dengan diterapkannya pendekatan STEM pada saat pembelajaran. Hal ini sesuai dengan pendapat Sudjana (2002) yaitu hasil belajar peserta didik adalah kemampuan-kemampuan yang telah dimiliki peserta didik setelah mereka menerima pengalaman proses belajar mengajar pada saat di kelas. Sehingga setelah peserta didik mengikuti proses belajar mengajar tersebut akan terjadi suatu perubahan di dalam diri peserta didik. Sebaliknya jika skor tes hasil belajar yang rendah atau di bawah KKM menunjukkan bahwa peserta didik kurang dapat memahami dan menguasai konsep dengan baik pada materi jarak antara dua titik dan jarak titik terhadap garis dengan diterapkannya pendekatan STEM pada saat pembelajaran.

Berdasarkan tes hasil belajar yang dilakukan 25 orang peserta didik, persentase ketuntasan keberhasilan hasil belajar secara klasikal sebesar 92\%. Dengan demikian, dapat dikatakan bahwa kelas XI jurusan BKP SMKN 3 Surabaya tuntas belajar mengenai materi jarak antara titik dan jarak titik terhadap garis karena persentase ketuntasan hasil belajar lebih dari $75 \%$.

Lembar angket respons peserta didik dikerjakan oleh peserta didik secara pembelajaran daring dengan menggunakan google form pada pertemuan ketiga setelah peserta didik mengerjakan soal tes hasil belajar.

Berdasarkan hasil analisis angket respons peserta didik dalam pembelajaran matematika dengan menerapkan pendekatan STEM pada materi jarak antara dua titik dan jarak titik terhadap garis terdapat respons sangat positif dan positif dari total 10 pernyataan yang telah diberikan kepada peserta didik. Yang memberikan respons sangat positif terdapat 5 dari 10 pertanyaan. Sedangkan yang memberikan respons positif terdapat 5 dari 10 pernyataan.

Pada pernyataan peserta didik lebih mudah memahami materi jarak antara dua titik dan jarak titik terhadap garis pada ruang dimensi tiga karena dikaitkan dengan science, technology, dan engineering yang sesuai dengan bidang keahliannya mendapat persentase sebesar $88 \%$ dengan kategori respons sangat positif. Hal tersebut sesuai dengan tujuan pembelajaran matematika SMK nomor lima yang dikemukakan oleh Permendiknas No. 22 (dalam Depdiknas, 2006) yaitu bahwa pembelajaran matematika akan sangat berguna dan bermakna bagi peserta didik SMK apabila mereka mengetahui kegunaan matematika dalam kehidupan. Peserta didik merasa bahwa LKPD yang diberikan oleh guru membantunya lebih antusias dalam belajar karena dikaitkan dengan science, technology, dan engineering yang sesuai dengan bidang keahlian mereka.

Selain hal tersebut pernyataan yang memiliki persentase tertinggi sebesar $91 \%$ dengan kategori respons sangat positif yaitu pada pernyataan dengan berdiskusi kelompok, peserta didik dapat belajar bekerja sama dengan teman sekelompok dalam memecahkan masalah. Hal tersebut sesuai dengan pendapat Winaryati (2018) yaitu dengan menerapkan pembelajaran dengan pendekatan STEM tersebut dapat menciptakan peserta didik memiliki keterampilan abad 21 di antaranya komunikasi, kolaborasi, berpikir kritis, dan kreativitas yang berguna bagi peserta didik untuk bersaing pada abad 21.

Pernyataan yang lain yaitu peserta didik merasa tertarik pada saat guru menjelaskan materi jarak antara dua titik dan jarak titik terhadap garis pada ruang dimensi tiga menggunakan alat-alat teknologi seperti geogebra dan powerpoint mendapatkan persentase $84 \%$ dengan kategori respons positif. Karena hal tersebut sesuai dengan tujuan teknologi menurut Khairiyah (2019) yaitu dengan adanya teknologi membuat peserta didik tertarik dalam belajar serta memudahkan peserta didik dalam menyelesaikan masalah pada saat kegiatan pembelajaran karena menghemat waktu dan biaya.

Pernyataan yang memiliki persentase terendah sebesar $70 \%$ dengan kategori respons positif yaitu pada pernyataan peserta didik dapat belajar materi jarak pada ruang dimensi tiga lebih baik tanpa LKPD yang diberikan oleh guru. Perolehan pernyataan unfovarable tersebut terjadi karena pada pembelajaran matematika yang dilakukan oleh guru matematika cenderung tidak menggunakan perangkat pembelajaran seperti LKPD. Sehingga respons peserta didik kurang terhadap penggunaan LKPD pada materi jarak antara dua titik dan jarak titik dengan garis.

Berdasarkan data hasil respons peserta didik setelah diterapkannya pembelajaran dengan pendekatan STEM, maka respons peserta didik secara keseluruhan dikatakan positif dengan persentase $82,4 \%$. Hal tersebut sesuai dengan kriteria yang ditetapkan pada bagian metode yaitu respons peserta didik dikatakan positif apabila secara keseluruhan mendapatkan persentase lebih dari $70 \%$. 


\section{PENUTUP \\ Simpulan}

Simpulan dalam penelitian ini ditulis berdasarkan hasil dan pembahasan yang telah dipaparkan yaitu kemampuan guru dalam mengelola pembelajaran dengan menerapkan pendekatan STEM termasuk dalam kategori sangat baik dengan skor rata-rata 3,53. Aktivitas peserta didik selama mengikuti pembelajaran dengan menerapkan pendekatan STEM termasuk dalam kategori aktif dengan persentase rata-rata sebesar $94 \%$ serta terdapat 5 aktivitas yang sesuai dan 5 aktivitas yang tidak sesuai dengan rentang waktu ideal. Hasil belajar peserta didik dilihat dari nilai tes hasil belajar memperoleh persentase ketuntasan belajar klasikal sebesar 92\%. Dan respons peserta didik secara keseluruhan mempunyai respons positif dengan rata-rata persentase respons sebesar $82,4 \%$.

Saran

Berdasarkan penelitian yang telah dilakukan, maka terdapat saran yang diberikan peneliti:

1. Bagi guru yang ingin mengajarkan materi jarak titik ke titik dan jarak titik ke garis pada ruang dimensi tiga dapat menggunakan pendekatan STEM sebagai alternatif dalam pembelajaran. Namun, guru harus mempersiapkan alat-alat teknologi seperti aplikasi geogebra, dsb sebelum pembelajaran dimulai.

2. Bagi peneliti yang akan melakukan penelitian sejenis, sebaiknya melakukan penganalisisan terlebih dahulu pada materi matematika yang akan diajarkan. Sebab pembelajaran dengan menggunakan pendekatan STEM harus mengaitkan empat disiplin ilmu. Misalnya aspek engineering, dengan aspek tersebut peneliti harus terlebih dahulu mengetahui keterampilan apa yang telah dimiliki oleh peserta didik SMK yang sesuai dengan bidang keahliannya sehingga penerapan aspek engineering akan menjadi lebih bermakna bagi mereka.

\section{DAFTAR PUSTAKA}

Firman, Harry. 2015. "Pendidikan Sains Berbasis Stem: Konsep, Pengembangan, Dan Peranan Riset Pascasarjana". Makalah disajikan dalam Seminar Nasional Pendidikan IPA dan PKLH, Bogor, 22 Agustus 2015.

Depdiknas. 2006. Permendiknas Nomor 22 Tahun 2006 Tentang Standar Isi Sekolah Menengah Atas. Jakarta: Depdiknas.

Devi, P.K., dkk. 2018. "Materi Bimbingan Teknis Pembelajaran Berbasis STEM dalam Kurikulum 2013”. SEAMEO QITEP In Science dengan Direktorat Pembinaan Sekolah Menengah Pertama.

Kemendikbud. 2014. Lampiran Peraturan Menteri Pendidikan dan Kebudayaan Republik Indonesia Nomor 103 Tahun 2014 Tentang Pembelajaran pada Pendidikan Dasar dan Menengah,(Online),(https://pgsd.uad.ac.id/wp- content/uploads/lampiran-permendikbud-no-103tahun-2014.pdf, diakses 5 November 2019).

Khabibah, Siti. 2006. Pengembangan Model Pembelajaran Matematika dengan Soal Terbuka untuk Meningkatkan Kreativitas Siswa Sekolah Dasar. Disertasi tidak diterbitkan. Surabaya: PPs Unesa.

Khairiyah, Nida'ul. 2019. Pendekatan Science, Technology, Engineering, dan Mathematics (STEM). Medan: Guepedia.

Masriyah. 2018. Asesmen Proses dan Hasil Belajar. Surabaya: Unipress UNESA.

Masriyah. 2006. Penyusunan Non Tes (Modul 9). Surabaya: Unipress UNESA.

Nurdyansyah \& Fahyuni, E.F. 2016. Inovasi Model Pembelajaran. Sidoarjo: Nizamia Learning Center.

P21. 2008. 21st Century Skills, Education \& Competitiveness. Washington DC: Partnership for 21st Century Skills.

Robert, A. \& Cantu, D. 2012. Applying STEM Instructional Strategies To Design And Technology Curriculum,

(Online), (http://www.ep.liu.se/ecp/073/013/ecp12073013.pdf, diakses pada 10 November 2019).

Saleha. 2019. STEM Menjawab Tantangan Abad 21. Batu: CV. Beta Aksara.

Sofyan, H., dkk. 2015. Pengembangan Model Pembelajaran Problem Based Learning dalam Implementasi Kurikulum 2013 di SMK, (Online),(https://eprints.uny.ac.id/36712/1/Herminart o\%20Sofyan_unggulan\%20PT.pdf, diakses pada 17 Januari 2020).

Sudjana. Nana. 2002. Penilaian Hasil Belajar Mengajar. Bandung: Rosida Karya.

Sudjana, Nana. 2011. Penilaian Hasil dan Proses Belajar Mengajar. Bandung: PT. Remaja Rosyadakarya.

Suparno. 2008. Bisnis konstruksi dan properti Jilid 1. Jakarta: Direktorat Pembinaan Sekolah Menengah Kerujuan.

Susanah, dkk. 2014. Strategi Pembelajaran Matematika (Edisi 2). Tangerang Selatan: Universitas Terbuka.

Torlakson, T. 2014. Innovate: A Blueprint For Science, Technology, Engineering, and Mathematics in California Public Education. California: State Superintendent of Public Instruction.

Trianto. 2007. Model-Model Pembelajaran Inovatif Berorientasi Konstruktivistik. Jakarta: Prestasi Pustaka.

Winaryati, Eny. 2018. "Penilaian Kompetensi Siswa Abad 21”. Seminar Nasional Edusainstek FMIPA UNIMUS. ISBN: 987-602-5614-35-4. 